\title{
The effect of habitat fragmentation and abiotic factors on fen plant occurrence
}

\author{
Hester Soomers • Derek Karssenberg • Jos T. A. Verhoeven • \\ Pita A. Verweij • Martin J. Wassen
}

Received: 4 May 2012/Accepted: 22 November 2012/Published online: 9 December 2012

(C) Springer Science+Business Media Dordrecht 2012

\begin{abstract}
Human landscape modification has led to habitat fragmentation for many species. Habitat fragmentation, leading to isolation, decrease in patch size and increased edge effect, is observed in fen ecosystems that comprise many endangered plant species. However, until now it has remained unclear whether habitat fragmentation per se has a significant additional negative effect on plant species persistence, besides habitat loss and degradation. We investigated the relative effect of isolation, habitat size, and habitat edge compared to the effect of habitat degradation by including both 'fragmentation variables' and abiotic variables in best subsets logistic regression analyses for six fen-plant species. For all but one species, besides abiotic variables one or more variables related to fragmentation were included in the regression model. For Carex lasiocarpa, isolation was the most important factor limiting species distribution, while for Juncus subnodulosus and Menyanthes trifoliata, isolation was the second most important factor. The effect of habitat size differed among species and an increasing edge had a negative effect on the occurrence of Carex lasiocarpa and Pedicularis palustris. Our results clearly show that even if abiotic
\end{abstract}

H. Soomers · M. J. Wassen $(\bowtie)$

Environmental Sciences, Copernicus Institute of Sustainable Development, Faculty of Geosciences, Utrecht University, P.O. Box 80115, 3508 TC Utrecht, The Netherlands

e-mail: M.J.Wassen@uu.nl

Present Address:

H. Soomers

Vereniging Natuurmonumenten, Regio Zuid-Holland en Zeeland, Stationsplein 45, 3013 AK

Rotterdam, The Netherlands

D. Karssenberg

Department of Physical Geography, Faculty of Geosciences, Utrecht University, PO Box 80115,

3508 TC Utrecht, The Netherlands

J. T. A. Verhoeven

Ecology and Biodiversity, Faculty of Science, Utrecht University, PO Box 80058, 3508 TB Utrecht, The Netherlands

P. A. Verweij

Energy and Resources, Faculty of Geosciences, Copernicus Institute of Sustainable Development, Utrecht University, PO Box 80058, 3508 TB Utrecht, The Netherlands 
conditions are suitable for certain species, isolation of habitat patches and an increased habitat edge caused by habitat fragmentation affect negatively the viability of characteristic fen plant species. Therefore, it is important not only to improve habitat quality but also to consider spatial characteristics of the habitat of target species when deciding on plant conservation strategies in intensively used landscapes, such as fen areas in Western Europe and North America.

Keywords Dispersal limitation - Habitat area - Habitat degradation - Habitat edge · Isolation · Logistic regression

\section{Introduction}

Over the last decades, human impact on nature has increased (Vitousek et al. 1997). Landscape modification has led to habitat loss and habitat degradation for many species. The former has negative effects on the persistence of species (Tilman et al. 1994) and thus on biodiversity (Fahrig 2003). The latter, often caused by eutrophication, desiccation and acidification, also decreases species viability in most ecosystems (Vitousek et al. 1997).

Habitat loss often leads to a fragmented distribution of the remaining habitat patches that are surrounded by a matrix of unsuitable land (Saunders et al. 1991). This causes a decrease in connectivity between the remaining subpopulations and a lower colonization probability of suitable but empty sites. Also, the number of populations and the size of habitat patches, and thus of populations usually decrease as a result of habitat fragmentation (Ouborg et al. 2006). Small, isolated populations are more susceptible to the negative effects of environmental and demographic stochasticity (Leimu et al. 2006). Furthermore, the influence of external conditions in such populations is greater than in large (non-linear) ones (Laurance and Yensen 1991) because of the increasing perimeter:area ratio with increasing fragmentation (edge effect) (Saunders et al. 1991). Last, genetic drift and inbreeding lead to a decrease in genetic diversity in small and isolated populations (Frankham 2005; Ouborg et al. 2006). For these reasons, fragmentation can have an additional negative effect on species viability, besides the negative effect of habitat loss and habitat degradation per se (Fahrig 2003).

In the literature, proposed plant conservation measures are often limited to restoring abiotic conditions (e.g. Suding et al. 2005; Wassen et al. 2005) and tend to ignore the effect of habitat configuration and dispersal limitation on biodiversity (Ozinga et al. 2009). Conversely, metapopulation models that consider habitat configuration and biotic processes, such as dispersal, often ignore habitat quality (e.g. Helm et al. 2006) by assuming that a habitat patch is either suitable or unsuitable for a species. Furthermore, seed sowing studies that aim at investigating whether seed dispersal limits species distribution by sowing seeds at unoccupied but potentially suitable sites often only consider germination, not establishment of species. Thereby, these studies ignore the possibility that adult plants are affected by other factors than seedlings, which can lead to erroneous conclusions on dispersal limitation (Ehrlen et al. 2006). Thus, to understand the dynamics of population extinction and (re)colonization in fragmented landscapes, it is necessary to consider the cumulative effects of abiotic and biotic factors on the performance of adult plant species. The relatively negative effect of isolation, decrease in population size, and increase in habitat edge compared to the effect of habitat degradation and loss per se, has remained largely unrevealed until now (but see Pueyo and Alados 2007). 
Habitat fragmentation is common in Dutch wetlands and the decline in habitat quality and quantity in them is most evident in nutrient-poor and groundwater-dependent ecosystems, such as species-rich fens (Runhaar et al. 1996). These fens contain many globally endangered plant species and communities which necessitates their conservation and restoration (Lamers et al. 2002).

The aims of this study are first, to determine the current degree of fragmentation of six rich-fen plant species in a Dutch fen area, and second, to disentangle the negative effects of habitat fragmentation from those caused by changes in abiotic site factors on the distribution of these six species. To determine the key factors that explain the presence of these species, a dataset comprising information on site factors and plant species composition was used. This dataset was expanded with four spatial variables that together encompass the different aspects of habitat fragmentation: (i) distance to the nearest (other) population, (ii) number of populations in the neighbourhood of sampling locations, (iii) habitat area, and (iv) habitat area: perimeter ratio, representing the edge effect (e.g. Fahrig 2003; Ouborg et al. 2006; Saunders et al. 1991). These variables were computed with a Geographical Information System (GIS) (ESRI 2006). One of our hypotheses is that these spatial variables contribute significantly to the explanation of species distribution. More specifically, it is hypothesised that the negative effect of dispersal limitation, decreasing habitat area, and increasing habitat edge will be more pronounced for rare species with severely fragmented populations than for more common and less fragmented species (see also Leimu et al. 2006). Another hypothesis is that the effect of habitat fragmentation will be more pronounced for species that only disperse over short distances (see also Ozinga et al. 2005).

\section{Methods}

Study site

The peatlands of the floodplain of the Vecht river in the central Netherlands originated in the Holocene epoch; rapid peat development was in the period 5000 y вC-1000 вP (Zonneveld 1980). The peatlands are bordered by the Pleistocene ice pushed hill ridge (0-30 $\mathrm{m}$ above msl.) of Het Gooi $\left(5^{\circ} 05^{\prime}-5^{\circ} 15^{\prime} \mathrm{E}\right.$ and $52^{\circ} 07^{\prime}-52^{\circ} 20^{\prime} \mathrm{N}$; Fig. 1). Rainwater infiltrating in the hill ridge discharges in the fens, leading to nutrient-poor, base-rich conditions. Peat was excavated since the 12th century, and many lakes originated because of these cutting and dredging activities. The remaining area was drained, and polders have been created since the 19th century. Fragmentation of regional groundwater seepage systems, mainly caused by drinking water abstractions and drainage to the lower-lying polders, has led to a decrease of seepage of base-rich nutrient-poor fresh groundwater that enters the root zone of plants, causing changes in site factors (Schot et al. 1988; Schot and Wassen 1993). This phenomenon produced a fragmented distribution of the remaining groundwater-dependent ecosystems.

Nowadays, most of the $120 \mathrm{~km}^{2}$ plain consists of lakes (c. $50 \mathrm{~km}^{2}$ ) and agricultural area (c. $50 \mathrm{~km}^{2}$ ). The remaining fens cover approximately $20 \mathrm{~km}^{2}$ and are located in scattered nature reserves. Peat depth is between 0.5 and $3 \mathrm{~m}$ and plant cover of these fens consist of herbaceous vegetation dominated by forbs, sedges and grasses and a well-developed moss layer. Water levels in the fens are at the ground surface in autumn, winter and spring and can drop to c. $40 \mathrm{~cm}$ in summer. Depending on the mix between infiltrating rainwater, upwelling groundwater and laterally inflowing surface water, $\mathrm{pH}$ of the shallow water in 


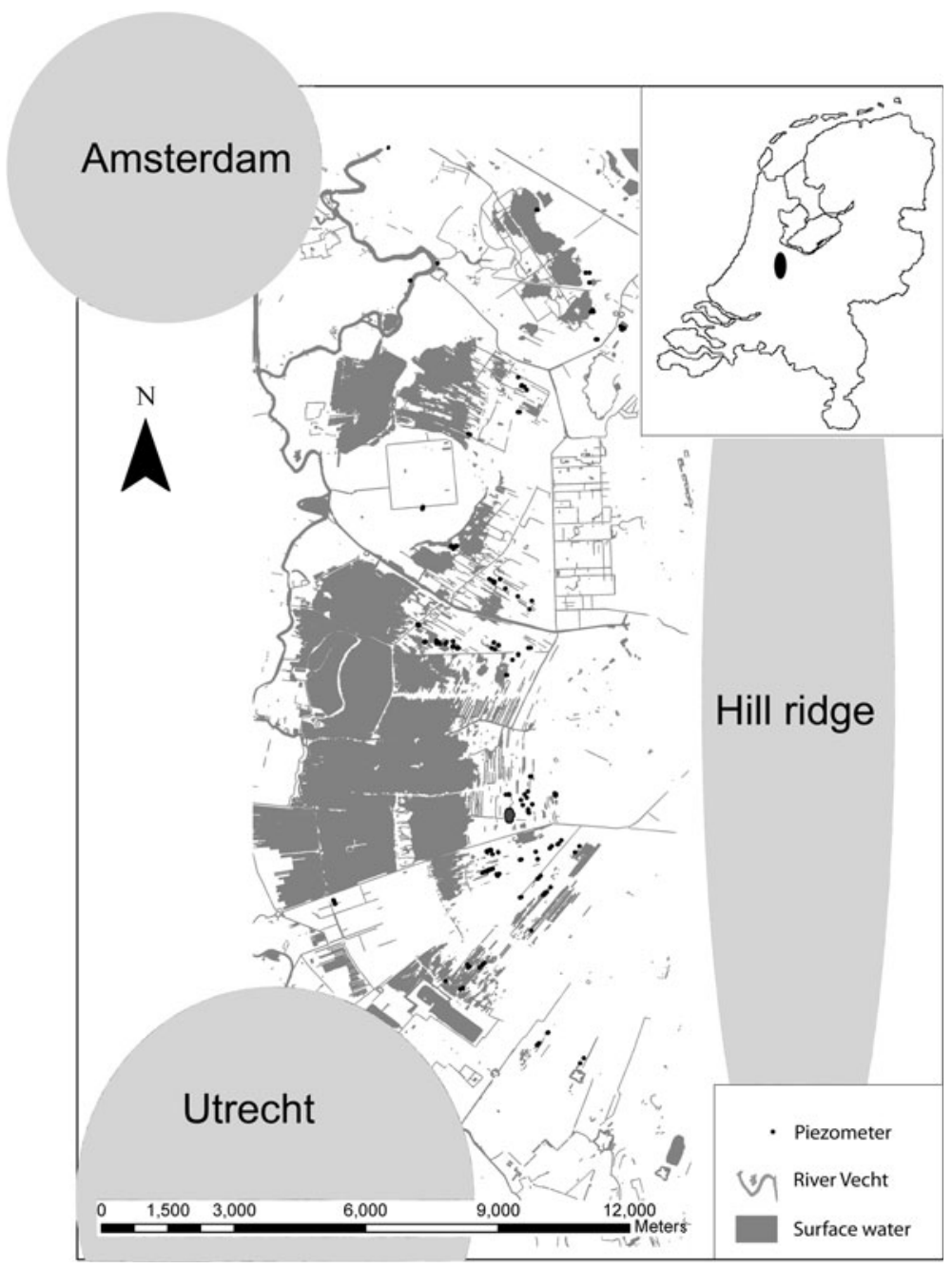

Fig. 1 The Vecht river plain with piezometer locations (point dataset). Inset: location of the study area in The Netherlands

the fens varies between 5.0 and 7.5 and electric conductivity (EC25) ranges between 10 and $60 \mathrm{mS} \mathrm{m} \mathrm{m}^{-1}$ (Wassen et al. 1989; 1990a; Wassen and Barendregt 1992).

Species descriptions

For six fen-plant species differing in abundance at the study site, the degree of fragmentation and the dependency on several abiotic and spatial factors were investigated. Four of these species are included in the Dutch Red List of vascular plant species (van der Meijden et al. 1991), i.e. Carex diandra (category: vulnerable), Carex lasiocarpa (vulnerable), Menyanthes trifoliata (nearly threatened) and Pedicularis palustris (vulnerable). The two other species, Juncus subnodulosus and Equisetum fluviatile, are more common in The 
Netherlands and also in the Vecht river plain. All considered species except $P$. palustris are perennial.

C. diandra and $C$. lasiocarpa are relatively rare small sedge species that have their optimum in the rare, relatively nutrient-poor but species-rich, floating fens (Parvocaricetea class) (Lamers et al. 2002) in the Vecht river plain.

$P$. palustris is a monocarpic hemiparasite with a primarily biennial life cycle (Schmidt and Jensen 2000). The species mainly occurs in floating (rich) fens and mesotrophic grasslands (Van der Meijden 1996).

M. trifoliata, which is protected by the Flora and Fauna Act in The Netherlands, is a helophyte occurring in shallow waters and on semi-terrestrial fens. This species is more common than $P$. palustris, $C$. diandra, and C. lasiocarpa (Van der Meijden 1996).

J. subnodulosus and E. fluviatile occur in small sedge fens and along ditches (Van der Meijden 1996). The latter can also occur in shallow water and in fens dominated by large sedges (Lamers et al. 2002). E. fluviatile, which is considered to be a seepage indicator, belongs to the class of the Equisetopsida and produces spores instead of seeds (Van der Meijden 1996).

Dispersal characteristics of all species are given in Table 1. Terminal velocity (i.e. falling velocity of seeds in still air $\left(\mathrm{m} \mathrm{s}^{-1}\right)$ ) is a seed trait that is an important determinant of the seed's ability to disperse via wind (Soons and Heil 2002) (the lower the terminal velocity, the farther the seed can disperse). Seed buoyancy (days) enables seeds to disperse (over large distances) via water.

General approach

We used point and polygon spatial data to test our hypotheses. The point data comprised species presence/absence data and data on abiotic factors at these points. The polygon data consisted of species distribution maps for each of the six fen species, a nature type map of the study area, and a topographic map of the study area.

For the floodplain of the Vecht river, we first quantified the current degree of fragmentation of each species using species distribution maps, and second determined the key factors that explain the presence of these fen species. The latter was realised by relating plant occurrence (presence/absence at points) to spatial variables and to abiotic factors, using logistic regression analyses.

The datasets used, and the variables that were computed from these datasets are described in Table 2. To create the species distribution and the vegetation type maps, species or vegetation type respectively were mapped per cadastral parcel.

\section{Current fragmentation}

Species distribution patterns were analysed using area covering species distribution maps (see Table 2) to estimate the current degree of fragmentation of each species. Thus, we computed (1) the total area of the parcels in which a species is present within the study area, (2) the distance from a population to the nearest population of the same species, averaged over all populations, (3) the percentage of $1 \times 1 \mathrm{~km}$ cells in the study area in which a species is present, (4) the mean number of populations per $1 \times 1 \mathrm{~km}$ cell, and (5) the total number of populations for all species. The grid cell size of $1 \times 1 \mathrm{~km}$ was chosen because this resolution corresponds well to the approximate maximum seed dispersal distance by wind and water of the considered species, which is c. $500 \mathrm{~m}$ (Soomers et al. 2010; Soons 2006). 
Table 1 Mean seed terminal velocity (i.e. falling velocity of seeds in still air $\left(\mathrm{m} \mathrm{s}^{-1}\right)$ ), seed buoyancy, other potential dispersal vectors, besides wind and surface water, and the assumed dominantly long distance dispersal vector of the studied fen-plant species

\begin{tabular}{lllll}
\hline Species & $\begin{array}{l}\text { Mean seed } \\
\text { terminal velocity } \\
(\mathrm{m} / \mathrm{s})^{\mathrm{a}}\end{array}$ & $\begin{array}{l}\text { Seed } \\
\text { buoyancy } \\
\text { (days) }\end{array}$ & $\begin{array}{l}\text { Seed dispersal vectors } \\
\text { (besides wind and }_{\text {water }^{\mathrm{c}}}\end{array}$ & $\begin{array}{l}\text { Hypothesised dominantly } \\
\text { long distance dispersal } \\
\text { vector }\end{array}$ \\
\hline Carex diandra & 2.6 & 99 & Ants, animal fur & Water \\
Carex lasiocarpa & 2.0 & $49^{\mathrm{f}}$ & Ants, animal fur & Water \\
Equisetum fluviatile & $?^{\mathrm{g}}$ & $?$ & $?$ & Wind \\
Juncus subnodulosus & $0.9-1.2^{\mathrm{e}}$ & 30 & Animal fur & Water \\
Menyanthes trifoliata & 3.85 & 119 & Animals (internally) & Water \\
Pedicularis palustris & 3.3 & 71 & Ants & Water \\
\hline
\end{tabular}

${ }^{a}$ Kleyer et al. (2008)

b The number of days after which $50 \%$ of the seeds have sunk in stagnant water (van den Broek et al. 2005)

c Bouman et al. (2000)

d This species produces spores, not seeds

e The value is unknown for this species. Values depicted here are based on two Juncus species with seed size, shape and weight comparable to that of $J$. subnodulosus: J. captitatus $(0.9 \mathrm{~m} / \mathrm{s})$ and $J$. compressus $(1.2 \mathrm{~m} / \mathrm{s})$

${ }^{\mathrm{f}}$ The value measured in moving water (approximately $0.06 \mathrm{~m} \mathrm{~s}^{-1}$ ) is presented here because of a missing value for stagnant water

$\mathrm{g}$ The Terminal velocity of spores of E. fluviatile is unknown. Nevertheless, it can be assumed to be very low $(<0.3 \mathrm{~m} / \mathrm{s}$, (Soons 2006)), due to the extremely small spore size (approximately $40 \mu \mathrm{m}$ (Lehmann et al. 1984))

h Species were characterised as long distant wind dispersers if terminal velocity $<0.3$ (Soons 2006) and as long distant water dispersers if seed buoyancy $>2$ days (Johansson et al. 1996)

Fragmentation was considered to be severe when the total area covered by a certain species was relatively small and the mean distance to the nearest population was relatively large (Fahrig 2003). Furthermore, one would expect that a highly fragmented (meta)population comprises a relatively small number of populations distributed over a relatively large number of cells. This would cause a low mean number of populations per occupied cell. Finally, the number of populations within an area can initially increase during the fragmentation process because existing populations divide, but eventually it will probably decrease because of habitat loss (Fahrig 2003).

Mean population size often decreases with increasing fragmentation (Ouborg et al. 2006). In our data, the size of each population was not registered, but was considered to be similar to the size of the cadastral parcel on which the population was growing, ignoring the possibility that the population did not cover the whole parcel. Therefore, this variable was not included.

\section{Regression analyses}

The presence of each plant species was related to abiotic factors and spatial variables by applying logistic regression analyses (see Table 2). The spatial variables included (Table 2) are often mentioned in the literature about habitat fragmentation (e.g. Ewers et al. 2007; Fahrig 2003; Saunders et al. 1991). The data used as input for these analyses are described below and shown in Table 2 . 
Table 2 Description of the variables computed for (1) the analysis of current fragmentation and (2) the regression analyses, using five datasets (rows), of which two were point and three were polygon data

\begin{tabular}{|c|c|c|c|}
\hline $\begin{array}{l}\text { Dataset } \\
\text { type }\end{array}$ & Datasets & $\begin{array}{l}\text { Analysis 1: current } \\
\text { fragmentation (for each } \\
\text { species separately) }\end{array}$ & $\begin{array}{l}\text { Analysis } 2 \text { : regression analyses }{ }^{\mathrm{e}} \text { (for each } \\
\text { species separately) }\end{array}$ \\
\hline \multirow[t]{2}{*}{ Point data } & $\begin{array}{l}\text { Species } \\
\text { presence/ } \\
\text { absence }^{\mathrm{a}}\end{array}$ & & Dependent variable \\
\hline & Abiotic factors $^{\mathrm{a}}$ & & Independent variables (equal for all species) \\
\hline \multirow[t]{3}{*}{$\begin{array}{l}\text { Polygon } \\
\text { data }\end{array}$} & $\begin{array}{l}\text { Species } \\
\text { distribution } \\
\text { maps }^{\text {b }}\end{array}$ & $\begin{array}{l}\text { Used to compute for each } \\
\text { species: } \\
\text { 1. Total area of all parcels } \\
\text { in which the species is } \\
\text { present } \\
\text { 2. Mean nearest neighbour } \\
\text { distance between } \\
\text { populations } \\
\text { 3. Percentage of occupied } \\
1 \times 1 \mathrm{~km} \text { cells } \\
\text { 4. Mean number of } \\
\text { populations per } 1 \times 1 \mathrm{~km} \\
\text { cell } \\
\text { 5. Number of populations }\end{array}$ & $\begin{array}{l}\text { Used to compute two independent variables } \\
\text { for each point in the point dataset: } \\
\text { 1. Number of populations within } 500 \mathrm{~m} \\
\text { 2. Distance to the nearest population }\end{array}$ \\
\hline & $\begin{array}{l}\text { Nature types } \\
\text { map }^{c}\end{array}$ & & $\begin{array}{l}\text { Used to compute two independent variables } \\
\text { for each point in the point dataset: } \\
\text { 1. Habitat area } \\
\text { 2. Area: perimeter }\end{array}$ \\
\hline & $\begin{array}{l}\text { Dutch } \\
\text { topographic } \\
\text { map (top 10) }\end{array}$ & & $\begin{array}{l}\text { Used to compute one independent variable } \\
\text { for each point in the point dataset: distance } \\
\text { to hill ridge (equal for all species). }\end{array}$ \\
\hline
\end{tabular}

${ }^{a}$ De Mars (1996) and Wassen and Barendregt (1992)

b Provincie Utrecht (2003); Province of Noord-Holland Unpublished results

c (c) Vereniging Natuurmonumenten, 's-Graveland; Provincie Utrecht (2003)

d Topografische Dienst (2005)

e Determining for each species the key factors (spatial and abiotic variables) that explain the presence of these fen species

\section{Datasets used for the regression analyses}

Point data: abiotic factors and species occurrence Data were obtained from previous projects that focused on the eco-hydrology of fens in the area. These data were used in the current analysis and comprise groundwater samples that were taken in the growing season (April-September) between 1986 and 1992 from piezometers with a filter depth of $50 \mathrm{~cm}$ below the soil surface $(\mathrm{n}=250)$ (Wassen et al. 1990a; Wassen and Barendregt 1992; De Mars 1996) (Fig. 1). Of these samples, Electro-Conductivity (EC25), pH, groundwater table relative to the peat surface, nutrients $\left(\mathrm{K}^{+}, \mathrm{NO}_{3}{ }^{-}, \mathrm{NH}_{4}{ }^{+}, \mathrm{H}_{2} \mathrm{PO}_{4}{ }^{-}, \mathrm{P}\right)(\mathrm{mg} / \mathrm{l})$ and major and minor ions $\left(\mathrm{Ca}^{2+}, \mathrm{Mg}^{2+}, \mathrm{Na}^{+}, \mathrm{Cl}^{-}, \mathrm{HCO}_{3}{ }^{-}, \mathrm{SO}_{4}{ }^{2-}, \mathrm{Fe}_{\text {tot }}\right)(\mathrm{mg} / \mathrm{l})$ were measured. At each sampling location, presence or absence of fen species was recorded in a $10 \mathrm{~m}^{2}$ plot. Data on the occurrence of $C$. diandra, C. lasiocarpa, M. trifoliata, P. palustris, J. subnodulosus and E. fluviatile were chosen from this database. Although it could be argued that sampling water chemistry at $50 \mathrm{~cm}$ below the ground surface is maybe too deep (outside the reach of plant 
roots), earlier research showed that correlations of species presences with water chemistry at this depth were strong not only in the studied fens but also in fens in eastern Poland where we applied the same method (Wassen et al. 1990b, 2006).

Polygon data: spatial variables In addition to the abiotic factors, four different spatial variables that are related in the literature to habitat fragmentation were included in the logistic regression analyses as independent variables (Table 2). These spatial variables were (1) number of populations within $500 \mathrm{~m}$, (2) distance to the nearest (other) population (related to isolation), (3) habitat area, and (4) habitat edge. Also, distance from the sampling location to the hill ridge was included as an independent variable. Several different GIS maps (polygon datasets) were used to compute these spatial variables (see Table 2). The private nature conservation organisation Natuurmonumenten and the province of Utrecht supplied maps of 'Nature Types' (CVereniging Natuurmonumenten, 's-Graveland; Provincie Utrecht 2003; scale 1:5000). The classification of Nature Types (see Table 2) includes vegetation types, such as quagfen and wet grassland, but also anthropogenic classes, such as road or garden. The spatial variables were constructed using the GIS package ArcGIS 9.1 (ESRI 2006).

For each sampling location, the distance to the hill ridge was computed using an overlay between the sampling location point map and the zero elevation isoline in the Dutch topographic map that represents the edge of the hill ridge.

Number of populations within $500 \mathrm{~m}$ and nearest population The number of populations within $500 \mathrm{~m}$ of each sampling location and the Euclidian distance to the centroid of the nearest (other) population from each sampling location were calculated using the area covering species distribution maps (Table 2). Polygons in each species distribution map that shared a common edge were merged as they were considered to be one population. For each species, both spatial variables were computed by making an overlay between the resulting species distribution polygon map and the map containing the sampling location points (point data). If a sampling location was situated within a population of the considered species, this population was not included in the computed number of nearby populations nor in the computed distance to the nearest population. The distance of $500 \mathrm{~m}$ was chosen because this is approximately the maximum seed dispersal distance of the considered species.

Habitat area and area:perimeter For each species, habitat was mapped by selecting the polygons of those Nature Types in which the species potentially can grow according to Vereniging Natuurmonumenten (C) Vereniging Natuurmonumenten, 's-Graveland) and Schaminée et al. (1995). These sources describe the vegetation types of moist and wet grasslands, marshes and fens in the area and for the entire Netherlands, including their characteristic floristic composition. Habitat was defined as a continuous patch suitable for the species. Polygons that shared a common edge were merged. Then, for each species, (1) habitat area and (2) habitat area: perimeter ratio of the habitat polygon that contained the sampling location were calculated at each sampling location.

When the sampling location was not inside any habitat polygon for a certain species, habitat area and area: perimeter ratio were set to 0 for the species under consideration.

\section{Analysis}

To gain insight into the key factors that determine plant presence for each of the considered species, 'best subsets logistic regression analyses' were run following the procedure 
described by King (2003) and using the statistical package SAS version 9.1. Abiotic and spatial variables were independent factors in the models, and presence/absence of plant species was the dependent factor. From all possible models, the model with the lowest Mallow's Cp value was chosen as the best model (Draper and Smith 1998). To check for consistency of the results, backward stepwise regression analyses with model selection through a likelihood ratio test were run and the results were compared to those of the best subsets regression.

To avoid collinearity or multi-collinearity (De Veaux and Ungar 1994), from groups of strongly correlating predictor variables $(r>0.8)$ only one was kept. This led to the omission of $\mathrm{pH}, \mathrm{Mg}^{2+}$ and $\mathrm{HCO}_{3}{ }^{-}$(strongly correlated with $\mathrm{Ca}^{2+}$ ) and omission of $\mathrm{Na}^{+}$ and $\mathrm{EC}_{25}$ (strongly correlated to $\mathrm{Cl}^{-}$). Because the habitat in which we sampled was relatively homogeneous, the gradient in the environmental data was relatively short and a linear species response to these data was found in an explorative data analysis. Therefore, only linear terms were included in the regression analyses (see Lepš and Šmilauer 2007). Single imputation was used to estimate missing values (Catellier et al. 2005), preventing loss of power due to a diminished sample size.

Moran's I values (Diniz-Filho et al. 2003; Legendre and Legendre 1998), obtained at seven distance intervals, were used to test for spatial autocorrelation in the standardised residuals of the regression models. Positive autocorrelation at small distances would indicate that certain explanatory variables were missing in the analyses (Diniz-Filho et al. 2003). Moran's I values were calculated using SAM software (Rangel et al. 2006). The statistical significance of these values was assessed using Monte Carlo randomization (200 permutations).

\section{Results}

Quantification of current fragmentation

The small sedge species $C$. diandra and $C$. lasiocarpa and the herbaceous species $P$. palustris have a small number of populations $(\leq 50)$, a total population area less than 100 ha (the total area of the study site is $26400 \mathrm{ha}$ ), and a relatively high mean nearest neighbour distance $(>370 \mathrm{~m}$ ) (Table 3). Conversely, the more common species E. fluviatile and $J$. subnodulosus have a considerably larger number of populations and total population area and a mean nearest neighbour distance below $220 \mathrm{~m}$. Furthermore, the percentage of occupied $1 \times 1 \mathrm{~km}$ cells is considerably higher for these species than for the above-mentioned species. Intermediate values for these variables were found for M. trifoliata (Table 3).

Regression analyses: key factors that determine species occurrence

Mean and standard deviation values for the independent variables included in the regression analyses are given in Appendix 1.

Spearman correlation coefficients for all pairs of abiotic independent variables included in the regression analyses are presented in Table 4 . The variables $\mathrm{pH}, \mathrm{Mg}^{2+}, \mathrm{Na}^{+}, \mathrm{HCO}_{3}{ }^{-}$, and $\mathrm{EC}_{25}$ correlated strongly $(r>0.8)$ with one or more other independent variables and were therefore excluded from the regression analysis and not listed in Table 4. Correlation coefficients $(r)$ for the remaining abiotic variables are between -0.6 and 0.6 (Table 4 ). The results of the best model (having the lowest Mallow's $C_{p}$ value) of the best-subsets logistic 
Table 3 Number of current populations of the considered species in the Vecht river plain, total area of the populations, mean nearest neighbour (NNB) distance for the populations, percentage of square kilometre cells in the study area that is occupied by the considered species, and the mean number of populations per occupied $1 \times 1 \mathrm{~km}$ cell for each of the considered species

\begin{tabular}{|c|c|c|c|c|c|}
\hline Species & $\begin{array}{l}\text { Number of } \\
\text { populations }\end{array}$ & $\begin{array}{l}\text { Total area } \\
\text { of } \\
\text { populations } \\
\left(\mathrm{m}^{2}\right)\end{array}$ & $\begin{array}{l}\text { Mean } \\
\text { NNB } \\
\text { distance } \\
(\mathrm{m})\end{array}$ & $\begin{array}{l}\text { Percentage }(\%) \text { of } \\
1 \times 1 \mathrm{~km} \text { cells in the } \\
\text { area that is occupied }\end{array}$ & $\begin{array}{l}\text { Mean number of } \\
\text { populations per } \\
\text { occupied } 1 \times 1 \mathrm{~km} \\
\text { cell }\end{array}$ \\
\hline Carex diandra & 35 & 673858 & 525.7 & 8.3 & 1.6 \\
\hline $\begin{array}{l}\text { Carex } \\
\quad \text { lasiocarpa }\end{array}$ & 50 & 900366 & 378.9 & 11.7 & 1.6 \\
\hline $\begin{array}{l}\text { Equisetum } \\
\text { fluviatile }\end{array}$ & 1107 & 4639995 & 120.2 & 49.2 & 8.5 \\
\hline $\begin{array}{l}\text { Juncus } \\
\quad \text { subnodulosus }\end{array}$ & 343 & 3676467 & 218.8 & 39.0 & 3.3 \\
\hline $\begin{array}{c}\text { Menyanthes } \\
\text { trifoliata }\end{array}$ & 95 & 1879093 & 338.3 & 17.0 & 2.1 \\
\hline $\begin{array}{c}\text { Pedicularis } \\
\text { palustris }\end{array}$ & 41 & 730333 & 491.9 & 12.5 & 1.2 \\
\hline
\end{tabular}

regression analyses for the six species are given in Table 5. For all but one species, the resulting regression models comprised both abiotic and spatial variables. Only for C. diandra, the model does not include spatial variables.

Species occurrence of all six species was negatively related to water table depth (i.e. wetter conditions were preferred; Table 5; Table 7 in Appendix). The presence of C. diandra, J. subnodulosus, E. fluviatile and M. trifoliata was positively related to the Calcium content of the groundwater (hereafter referred to as [Ca]), while [Ca] was negatively, but not significantly related to the presence of $C$. lasiocarpa. $[\mathrm{Cl}]$ was negatively related to both the occurrence of $C$. diandra and $M$. trifoliata.

A negative significant relation between species occurrence and the contents of the nutrients $\mathrm{K}$ (C. lasiocarpa and E. fluviatile), $\mathrm{PO}_{4}$ (J. subnodulosus, E. fluviatile, and M. trifoliata), $\mathrm{NO}_{3}$ (J. subnodulosus) and $\mathrm{NH}_{4}$ (P. palustris) was found. Conversely, a positively significant relation was found between the occurrence of $M$. trifoliata and E. fluviatile and both $\left[\mathrm{NH}_{4}\right]$ and $[\mathrm{P}]$.

The occurrence of J. subnodulosus was significantly positive related to the number of populations within $500 \mathrm{~m}$ of the sampling location, while the occurrence of both M. trifoliata and C. lasiocarpa was negatively related to the distance from the sampling location to the nearest population. The area: perimeter ratio of the habitat patch was positively related to the occurrence of $C$. lasiocarpa and $P$. palustris, which suggests a negative effect of an increasing edge length for these species.

The presence of $J$. subnodulosus was significantly positively related to the habitat area, while the occurrence of $E$. fluviatile and $P$. palustris were significantly negatively related to the habitat area.

For all species, backward stepwise regression analyses with model selection through a likelihood ratio test produced results similar to best-subsets regression for all species. The only difference between the two methods was an additional negative, non-significant $(P=0.115)$ relation between the occurrence of $C$. diandra and the distance to the hill ridge when running the stepwise regression. 
The standardised model residuals for $C$. lasiocarpa and $P$. palustris were significantly spatially auto-correlated for the first separation lag $(500 \mathrm{~m})$ in a Moran's I autocorrelation analysis. For $M$. trifoliata and $P$. palustris, the standardised residuals were positively spatially auto-correlated from 1000 to $2000 \mathrm{~m}$ and from 2000 to $2500 \mathrm{~m}$, respectively (Table 6).

\section{Discussion}

We have investigated whether spatial variables related to habitat fragmentation have an additional effect on the distribution of rich-fen plant species, on top of the effect of abiotic site factors. We expected that spatial variables contributed significantly to the explanation of species occurrences.

The results of the regression analyses clearly confirm the hypothesis that there is an additional negative effect of habitat fragmentation on the occurrence of fen plant species besides the negative effect of habitat degradation. For all species, except for $C$. diandra, one or more variables related to fragmentation were included in the best regression model. For C. lasiocarpa (distance to the nearest population) and P. palustris (area: perimeter ratio), the highest Wald values in the regression model were even attributed to a 'fragmentation variable'.

The Morans' I values demonstrate that in spite of the inclusion of dispersal-related variables in the regression models for three species, some spatial autocorrelation remained present in the model residuals. This might indicate that explanatory variables are missing (Diniz-Filho et al. 2003). Furthermore, spatial autocorrelation in the model residuals could exaggerate the strength of the relations (Whittaker et al. 2007). However, Hawkins et al. (2007) found that, at least for ordinary least squares regression of gridded geographical data, regression coefficients were not seriously affected by the presence of spatial autocorrelation (see also Bini et al. 2009). Thus, the presence of some autocorrelation for three of the species would not change our major conclusion that both abiotic factors and spatial configuration of habitat patches influence fen-plant-species distribution.

The results did not support our hypothesis that species for which the populations are already fragmented would be more prone to negative effects of habitat fragmentation.

Table 4 Spearman correlation coefficients for all combinations of abiotic factors

\begin{tabular}{|c|c|c|c|c|c|c|c|c|c|c|}
\hline & WL & $\mathrm{Ca}$ & $\mathrm{Cl}$ & $\mathrm{Fe}$ & $\mathrm{K}$ & $\mathrm{NH}_{4}$ & $\mathrm{NO}_{3}$ & $\mathrm{PO}_{4}$ & $\mathrm{SO}_{4}$ & $\mathrm{P}$ \\
\hline WL & - & $0.134 *$ & $0.232 * *$ & -0.074 & 0.018 & -0.105 & 0.021 & 0.027 & $-0.201 * *$ & -0.048 \\
\hline $\mathrm{Ca}$ & & - & $0.265^{* *}$ & 0.084 & $0.137 *$ & -0.123 & $-0.183^{* *}$ & -0.081 & 0.088 & $-0.130 *$ \\
\hline $\mathrm{Cl}$ & & & - & $-0.166^{* *}$ & $0.365 * *$ & $-0.139 *$ & -0.053 & 0.059 & 0.030 & -0.029 \\
\hline $\mathrm{Fe}$ & & & & - & $-0.255^{* *}$ & $-0.194 * *$ & $-0.396^{* *}$ & $-0.223 * *$ & $0.590 * *$ & $0.139 *$ \\
\hline K & & & & & - & $0.239 * *$ & $0.261 * *$ & $0.189 * *$ & -0.059 & $0.126^{*}$ \\
\hline $\mathrm{NH}_{4}$ & & & & & & - & $0.323^{* *}$ & $0.324^{* *}$ & -0.121 & $0.161^{*}$ \\
\hline $\mathrm{NO}_{3}$ & & & & & & & - & $0.543 * *$ & $-0.395 * *$ & $0.144 *$ \\
\hline $\mathrm{PO}_{4}$ & & & & & & & & - & $-0.383^{* *}$ & $0.422 * *$ \\
\hline $\mathrm{SO}_{4}$ & & & & & & & & & - & 0.033 \\
\hline $\mathrm{P}$ & & & & & & & & & & - \\
\hline
\end{tabular}

WL groundwater level below ground surface; other variables: concentrations of nutrients and ions in groundwater

$* P<0.05, * * P<0.01$ 


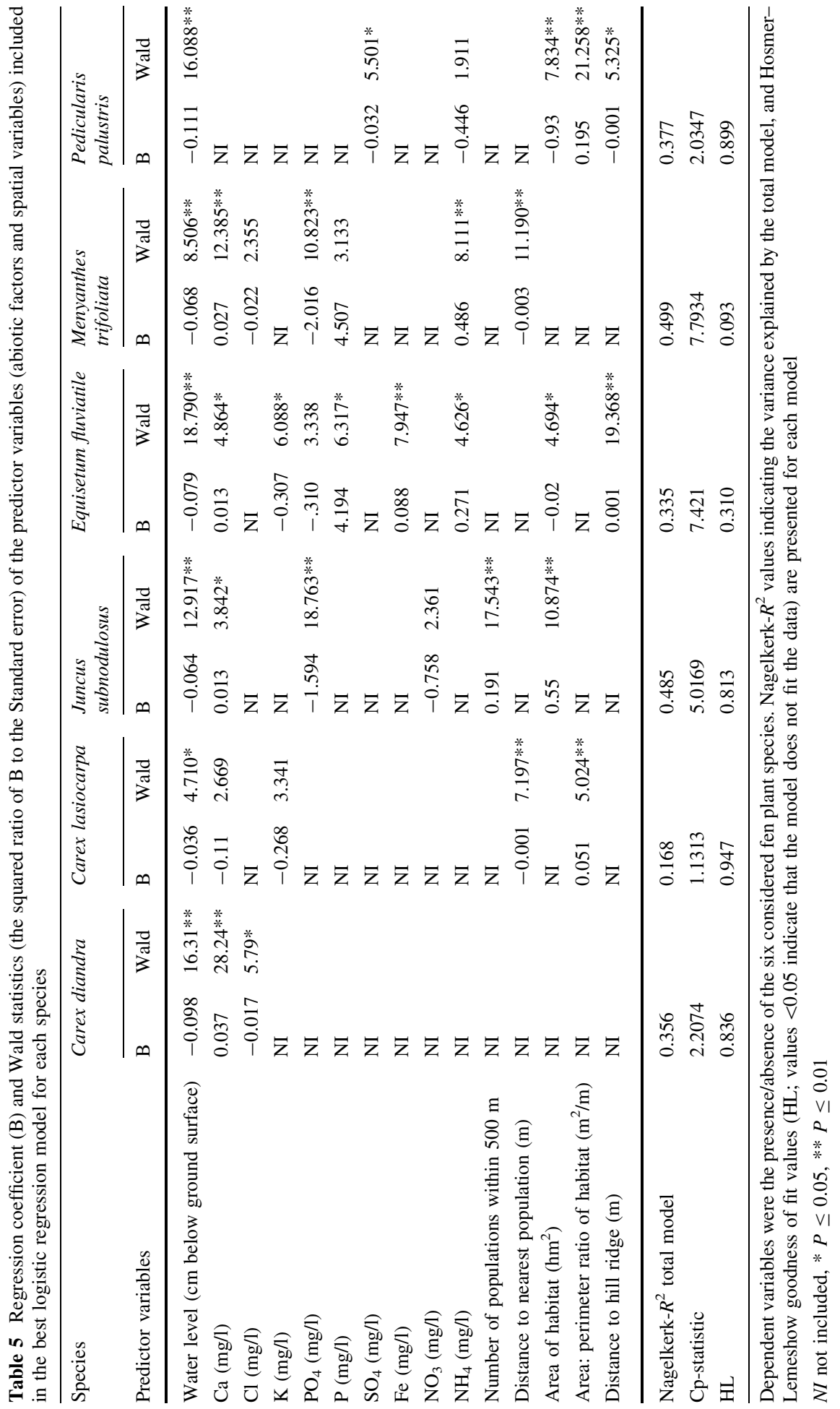




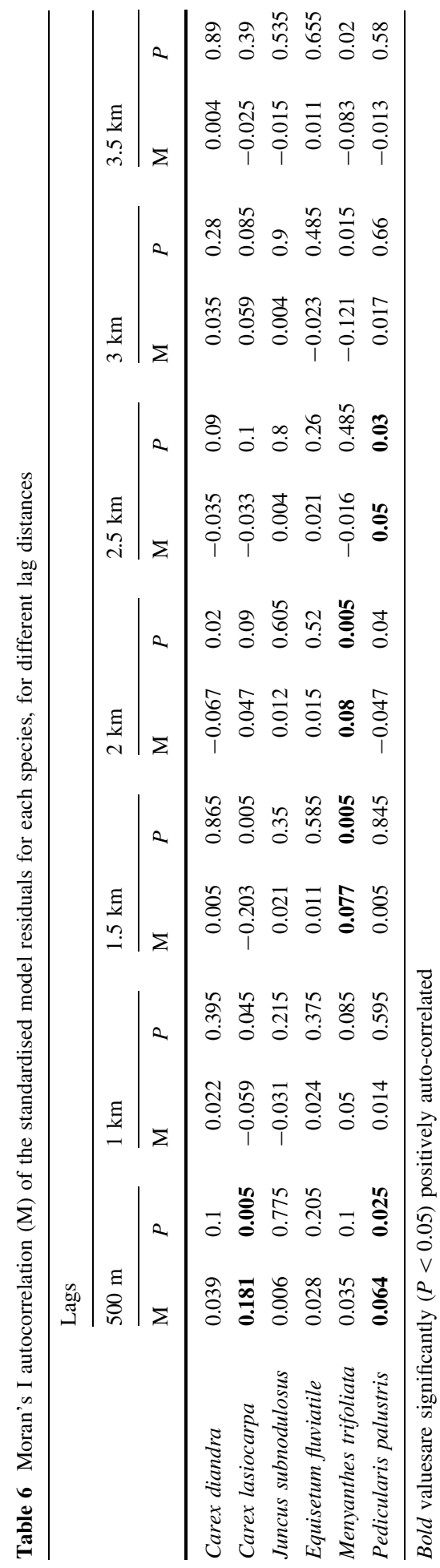


Rare species such as Carex diandra, Carex lasiocarpa and Potentilla palustris as well as common species such as Equisetum fluviatile, Juncus subnodulosus and Menyanthes trifoliata all were negatively affected by the effects of habitat fragmentation (Tables 3, 5). Leimu et al. (2006) report that rare species tend to be more susceptible to the negative effects of habitat fragmentation than common species although their results were not significant. Conversely, Honnay and Jacquemyn (2007) found that the genetic consequences of habitat fragmentation were equally or more pronounced in common than in rare species. To clarify this issue, more research is needed.

\section{Dispersal limitation}

Habitat fragmentation leads to isolation of the remaining habitat patches (Hanski 1999). Consequently, dispersal capacity of species in fragmented areas can limit species persistence (Ozinga et al. 2009). It can then be assumed that the probability that a species occurs at a certain suitable site would increase with decreasing distance to the nearest population (i.e. seed source), and with increasing number of populations nearby. This is reflected in the results found for J. subnodulosus, C. lasiocarpa, and M. trifoliata. For J. subnodulosus, the probability of occurrence increased with increasing number of nearby populations, while for $C$. lasiocarpa and $M$. trifoliata the probability of occurrence increased with decreasing distance to the nearest population. These highly significant results indicate that seed dispersal is limiting species distribution of J. subnodulosus, C. lasiocarpa, and M. trifoliata. Similar results were found for a semi-arid area by Pueyo and Alados (2007), who conclude that the re-establishment of the steppe species Lygeum spartum in a fragmented Mediterranean area was most strongly related to the distance to propagule sources. Our results are also congruent with findings of the long-term seed sowing study by Ehrlen et al. (2006), in which it was observed that establishment of forest herbs can occur after sowing in sites unoccupied by adult plants of the same species and in which hence is concluded that these forest herbs were limited by seed dispersal. Nevertheless, no effect related to dispersal limitation was found for the abundant species E. fluviatile and for the rare species $C$. diandra and $P$. palustris. It can be expected that for the wind dispersed E. fluviatile, distances between suitable habitat patches are too short to impair colonization probability. Conversely, the occurrence of both highly fragmented and rare Red List species $C$. diandra and $P$. palustris was not promoted by a close distance or large number of neighbouring populations either. Long-distance dispersal for these species is most likely to be realised via surface water (Table 1). However, surface water can only enhance colonization probability or connectivity for hydrochorous (i.e. water dispersing) species if the water bodies connect seed sources with potentially suitable habitat. If this is not the case, seeds of highly fragmented species with few populations and narrow ecological amplitudes, such as $C$. diandra and $P$. palustris, will not be able to colonize new habitat patches, even if these are nearby. We expect that this could explain that small distances to a population or many populations within a certain distance were not related to a higher probability of occurrence for $C$. diandra and $P$. palustris. These results stress the importance of further research on dispersal mechanisms of plant species in fragmented habitats and the importance of the improvement of the dispersal infrastructure for such species. Ozinga et al. (2009) indeed indicate that the dispersal infrastructure (i.e. the spatial structure of the dispersal vector, e.g. surface water, of a species) for many species in North-western Europe is insufficient. Thus, although our results reflect that seed dispersal limitation negatively affects the distribution of rich-fen species, additional to the negative effect of habitat degradation, the hypothesis that the effect of habitat 
fragmentation will be more important for species that only disperse over short distances was not supported. Future research should focus on effective dispersal distances instead of potential Euclidian dispersal distances, considering the dispersal infrastructure of the considered species.

Edge and area effect

In general, the proximity of habitat edges can have a positive, negative or neutral effect on species abundance and on biodiversity inside a given habitat, depending on the edge type and the species' life history strategies and habitat requirements (see reviews of Ewers and Didham 2005; Saunders et al. 1991). In habitat patches with a small area: perimeter ratio, the effect of the external conditions will be relatively greater, causing a smaller survival probability in these patches if the effect of the edge is negative.

In our study area, habitat patches are surrounded by a matrix of unsuitable agricultural land in which rare species with a narrow ecological amplitude, such as C. lasiocarpa and $P$. palustris, cannot establish. The results for $C$. lasiocarpa and $P$. palustris demonstrate that these species are more likely to be present in patches that have a relatively large area: perimeter ratio. This indicates that these species might be occurring more often in round than in linearly shaped landscape elements, which suggests that these species may suffer from the 'edge effect' (e.g. Saunders et al. 1991). However, these findings could also be explained by the fact that the two species usually do not occur in linearly shaped landscape elements, such as ditches or ditch banks, because the site factors tend to be unsuitable (i.e. too nutrient rich) for them.

It should be noted that it is difficult to disentangle an edge and an area effect, as synergistic interaction between these two variables can determine species occurrence (Ewers et al. 2007). Nevertheless, Smith et al. (2009) state that when trying to evaluate the relative effect of different fragmentation related predictors, such as amount of habitat, mean patch size and edge length, on species abundance, standard multiple regression performs as well as or better than methods that consider collinearity.

Habitat area was, as expected, positively related to species occurrence for J. subnodulosus. However, a negative relation between habitat size and species occurrence was found for E. fluviatile and $P$. palustris. The negative relation found for E. fluviatile might be caused because this species abundantly occurs at line elements with a usually small area, such as ditch banks, in the study site.

Collins et al. (2009) found that woody encroachment progressed faster in larger patches, leading to less favourable germination conditions for early-successional species. This effect possibly caused the negative relation between patch size and the persistence of annual early-successional species found by Collins et al. (2009). If woody encroachment also progresses faster in larger patches in our study site, the negative relation between habitat size and species occurrence found for the biannual species $P$. palustris could be explained by that mechanism.

\section{Abiotic factors}

Generally, the occurrence of most species was negatively related to the contents of one or more nutrients. Furthermore, all species occurred more often at sites with higher water tables and most of the species preferred sites with high calcium content.This agrees with the results of studies by for example van Diggelen et al. (1996) and Sjors and Gunnarsson (2002), who concluded that species of low productive rich-fens tend to persist at alkaline 
wet sites. These conditions are usually present at groundwater discharge sites, or at sites supplied by mineral rich but relatively nutrient poor surface water. Therefore, our results indicate that it is important to enhance discharge of calcium rich groundwater in the study site or to enable the supply of clean, nutrient poor, alkaline surface water to rich fen patches or potential rich fen sites.

\section{Implications for nature conservation and further research}

Our results show that even if abiotic conditions are suitable for certain species, isolation of habitat patches and decreased area: perimeter ratios of these patches negatively influence the viability of the investigated fen plant species. Since for the majority of the fen plant species fragmentation indicators add significantly to the explanation of their occurrences, we conclude that it is important not only to improve habitat quality, but also to connect fragmented populations acknowledging the dispersal capacity and the dominant dispersal vectors of fen-plant species. Providing general, quantitative values for minimum required patch size or maximum allowable distance between habitats is difficult, because these values depend on a large number of factors, most importantly species dispersal characteristics, hydrochorous dispersal landscape infrastructure, and climatology affecting anemochory.

Furthermore, it would be advisable to restore rich-fen vegetation in such a way that circular rather than linear areas (the latter having relatively more edge) are created and that newly created habitat patches are situated within the dispersal range of the species. When attempting to improve the dispersal infrastructure for hydrochorous species, one should ensure that subpopulations are connected by the same water body and that water borne seeds of (semi)terrestrial species can be deposited at suitable germination sites. The latter could be realised by the creation of shallow ditch banks or lake shores (Soomers et al. 2010).

Although our study focused on fens and plant species only, we may generalize the results to other ecosystems and species. In densely populated areas, such as Western Europe and North America, many ecosystems suffer from both deterioration of habitat quality (by for instance diffuse pollution via airborne or waterborne pollutants) as well as from a fragmented distribution of the remaining habitat patches. Intensive land use and drainage has transformed most of the rural area into unsuitable 'deserts' for species of forests, nutrient-poor grasslands and lakes, for example. Therefore, our results stress the importance of considering both habitat quality and connectivity in restoration attempts in intensively used landscapes. This requires the development of models that consider both aspects.

Acknowledgments The authors thank the Province of Utrecht, the Province of Noord-Holland, and Vereniging Natuurmonumenten for providing data and Hans de Mars for collecting data; Maarten Zeylmans van Emmichoven for his advice on GIS procedures and Rogier Donders for his advice on statistics. Hester Soomers' contribution was funded by the Utrecht Centre of Geosciences.

\section{Appendix}

See Table 7. 
Table 7 The means and standard deviations for each variable

\begin{tabular}{|c|c|c|c|}
\hline Species & Variable & Mean & $\mathrm{SD}$ \\
\hline All & Water level ( $\mathrm{cm}$ below ground surface) & 11.14 & 10.85 \\
\hline All & $\mathrm{Ca}(\mathrm{mg} / \mathrm{l})$ & 40.47 & 27.68 \\
\hline All & $\mathrm{Cl}(\mathrm{mg} / \mathrm{l})$ & 33.39 & 33.87 \\
\hline All & $\mathrm{K}(\mathrm{mg} / \mathrm{l})$ & 1.33 & 1.63 \\
\hline All & $\mathrm{PO}_{4}(\mathrm{mg} / \mathrm{l})$ & 0.87 & 1.22 \\
\hline All & $\mathrm{P}(\mathrm{mg} / \mathrm{l})$ & 0.087 & 0.116 \\
\hline All & $\mathrm{SO}_{4}(\mathrm{mg} / \mathrm{l})$ & 26.44 & 21.99 \\
\hline All & $\mathrm{Fe}(\mathrm{mg} / \mathrm{l})$ & 3.29 & 5.29 \\
\hline All & $\mathrm{NO}_{3}(\mathrm{mg} / \mathrm{l})$ & 0.64 & 0.81 \\
\hline All & $\mathrm{NH}_{4}(\mathrm{mg} / \mathrm{l})$ & 0.73 & 1.32 \\
\hline All & Distance to hill ridge $(\mathrm{m})$ & 1759.65 & 1013.47 \\
\hline Carex diandra & $\mathrm{A}: \mathrm{P}$ & 5.24 & 7.08 \\
\hline Carex diandra & DNP & 753.16 & 896.01 \\
\hline Carex diandra & AREA & 4824.66 & 8456.47 \\
\hline Carex diandra & NRPOP & 1.348 & 1.718 \\
\hline Carex lasiocarpa & $\mathrm{A}: \mathrm{P}$ & 5.4186 & 7.0135 \\
\hline Carex lasiocarpa & DNP & 839.03 & 1150.54 \\
\hline Carex lasiocarpa & AREA & 4572.26 & 8082.25 \\
\hline Carex lasiocarpa & NRPOP & 1.98 & 2.06 \\
\hline Juncus subnodulosus & $\mathrm{A}: \mathrm{P}$ & 6.053 & 6.905 \\
\hline Juncus subnodulosus & DNP & 214.79 & 377.90 \\
\hline Juncus subnodulosus & AREA & 6035.91 & 10740.41 \\
\hline Juncus subnodulosus & NRPOP & 7.57 & 4.02 \\
\hline Equisetum fluviatile & $\mathrm{A}: \mathrm{P}$ & 8.772 & 17.176 \\
\hline Equisetum fluviatile & DNP & 157.73 & 113.43 \\
\hline Equisetum fluviatile & AREA & 103197.73 & 455205.46 \\
\hline Equisetum fluviatile & NRPOP & 12.696 & 6.651 \\
\hline Menyanthes trifoliata & $\mathrm{A}: \mathrm{P}$ & 7.804 & 14.121 \\
\hline Menyanthes trifoliata & DNP & 505.52 & 641.66 \\
\hline Menyanthes trifoliata & AREA & 93159.76 & 323081.98 \\
\hline Menyanthes trifoliata & NRPOP & 3.52 & 3.08 \\
\hline Pedicularis palustris & A:P & 5.044 & 6.999 \\
\hline Pedicularis palustris & DNP & 478.08 & 543.49 \\
\hline Pedicularis palustris & AREA & 4308.40 & 8043.89 \\
\hline Pedicularis palustris & NRPOP & 1.54 & 1.74 \\
\hline
\end{tabular}

The 'fragmentation variables' are specific for each species

$A: P$ Area: perimeter ratio of habitat $\left(\mathrm{m}^{2} / \mathrm{m}\right), D N P$ distance to nearest population $(\mathrm{m}), A R E A$ area of habitat $\left(\mathrm{m}^{2}\right)$, NRPOP number of other populations within $500 \mathrm{~m}$ of the sampling location

\section{References}

Bini LM, Diniz-Filho JAF, Rangel TFLVB, Akre TSB, Albaladejo RG, Albuquerque FS, Aparicio A, Araújo MB, Baselga A, Beck J, Bellocq MI, Böhning-Gaese K, Borges PAV, Castro-Parga I, Chey VK, Chown SL, De Marco P Jr, Dobkin DS, Ferrer-Castán D, Field R, Filloy J, Fleishman E, Gómez 
JF, Hortal J, Iverson JB, Kerr JT, Kissling WD, Kitching IJ, León-Cortés JL, Lobo JM, Montoya D, Morales-Castilla I, Moreno JC, Oberdorff T, Olalla-Tárraga MA, Pausas JG, Qian H, Rahbek C, Rodríguez MA, Rueda M, Ruggiero A, Sackmann P, Sanders NJ, Terribile LC, Vetaas OR, Hawkins BA (2009) Coefficient shifts in geographical ecology: an empirical evaluation of spatial and nonspatial regression. Ecography 32:193-204

Bouman F, Boesewinkel D, Bregman R, Devente N, Oostermeijer G (2000) Verspreiding van. zaden. KNNV Uitgeverij, Utrecht

Catellier DJ, Hannan PJ, Murray DM, Addy CL, Conway TL, Yang S, Rice JC (2005) Imputation of missing data when measuring physical activity by accelerometry. Med Sci Sports Exerc 37:S555-S562

Collins CD, Holt RD, Foster BL (2009) Patch size effects on plant species decline in an experimentally fragmented landscape. Ecology 90:2577-2588

De Mars H (1996) Chemical and physical dynamics of fen hydro-ecology, p. 167. Rijksuniversiteit Utrecht, Utrecht

De Veaux RD, Ungar LH (1994) Multicollinearity: a tale of two nonparametric regressions. In: Cheeseman P, Oldford RW (eds) Selecting models from data: AI and statistics IV. Springer, New York, pp 293-302

Diniz-Filho JA, Bini LM, Hawkins BA (2003) Spatial autocorrelation and red herrings in geographical ecology. Glob Ecol Biogeogr 12:53-64

Draper NR, Smith H (1998) Applied regression analysis, 3rd edn. Wiley, New York

Ehrlen J, Münzbergová Z, Diekmann M, Eriksson O (2006) Long-term assessment of seed limitation in plants: results from an 11-year experiment. J Ecol 94:1224-1232

ESRI (2006) ArcGIS 9.1. Environmental Systems Research Institute, California

Ewers RM, Didham RK (2005) Confounding factors in the detection of species responses to 21 habitat fragmentation. Biol Rev 81:117-142

Ewers RM, Thorpe S, Didham RK (2007) Synergistic interactions between edge and area effects in a heavily fragmented landscape. Ecology 88:96-106

Fahrig L (2003) Effects of habitat fragmentation on biodiversity. Annu Rev Ecol Evol Syst 34:487-515

Frankham R (2005) Genetics and extinction. Biol Conserv 126:131-140

Hanski I (1999) Metapopulation ecology. Oxford University Press, Oxford

Hawkins BA, Diniz-Filho JAF, Mauricio Bini L, De Marco P, Blackburn TM (2007) Red herrings revisited: spatial autocorrelation and parameter estimation in geographical ecology. Ecography 30:375-384

Helm A, Hanski I, Partel M (2006) Slow response of plant species richness to habitat loss and fragmentation. Ecol Lett 9:72-77

Honnay O, Jacquemyn H (2007) Susceptibility of common and rare plant species to the genetic consequences of habitat fragmentation. Conserv Biol 21:823-831

Johansson ME, Nilsson C, Nilsson E (1996) Do rivers function as corridors for plant dispersal? J Veg Sci 7:593-598

King JE (2003) Running a best-subsets logistic regression: an alternative to stepwise ethods. Edu Psychol Meas 63:392-403

Kleyer MR, Bekker M, Knevel IC, Bakker JP, Thompson K, Sonnenschein M, Poschlod P, van Groenendael JM, Klimes L, Klimesová J, Klotz S, Rusch GM, Hermy M, Adriaens D, Boedeltje G, Bossuyt B, Dannemann A, Endels P, Götzenberger L, Hodgson JG, Jackel A-K, Kühn I, Kunzmann D, Ozinga WA, Römermann C, Stadler M, Schlegelmilch J, Steendam HJ, Tackenberg O, Wilmann B, Cornelissen JHC, Eriksson O, Garnier E, Peco B (2008) The LEDA traitbase: a database of life-history traits of the northwest European flora. J Ecol 96:1266-1274

Lamers LPM, Smolders AJP, Roelofs JGM (2002) The restoration of fens in The Netherlands. Hydrobiologia 478:107-130

Laurance WF, Yensen E (1991) Predicting the impacts of edge effects in fragmented habitats. Biol Conserv 55:77-92

Legendre P, Legendre L (1998) Numerical ecology. Elsevier, Amsterdam 22

Lehmann H, Neidhart HV, Schlenkermann G (1984) Ultrastructural investigations on sporogenesis in Equisetum fluviatile. Protoplasma 123:38-47

Leimu R, Mutikainen P, Koricheva J, Fischer M (2006) How general are positive relationships between plant population size, fitness and genetic variation? J Ecol 94:942-952

Lepš J, Šmilauer P (2007) Multivariate analysis of ecological data using CANOCO. Cambridge University Press, Cambridge

Ouborg NJ, Vergeer P, Mix C (2006) The rough edges of the conservation genetics paradigm for plants. J Ecol 94:1233-1248

Ozinga WA, Schaminee JHJ, Bekker RM, Bonn S, Poschlod P, Tackenberg O, Bakker J, van Groenendael JM (2005) Predictability of plant species composition from environmental conditions is constrained by dispersal limitation. Oikos 108:555-561 
Ozinga WA, Römermann C, Bekker RM, Prinzing A, Tamis WLM, Schaminée JHJ, Hennekens SM, Thompson K, Poschlod P, Kleyer M, Bakker JP, van Groenendael JM (2009) Dispersal failure contributes to plant losses in NW Europe. Ecol Lett 12:66-74

Provincie Utrecht (2003) Handleiding 2003, Ecologisch Onderzoek, onderdeel Flora en Vegetatie. Sector Ecologisch onderzoek en Groene regelgeving, Utrecht

Pueyo Y, Alados CL (2007) Effects of fragmentation, abiotic factors and land use on vegetation recovery in a semi-arid Mediterranean area. Basic Appl Ecol 8:158-170

Rangel TFLVB, Diniz-Filho JAF, Bini LM (2006) Towards an integrated computational tool for spatial analysis in macroecology and biogeography. Glob Ecol Biogeogr 15(4):321-327

Runhaar J, vanGool CR, Groen CLG (1996) Impact of hydrological changes on nature conservation areas in The Netherlands. Biol Conserv 76:269-276

Saunders DA, Hobbs RJ, Margules CR (1991) Biological consequences of ecosystem fragmentation-a review. Conserv Biol 5:18-32

Schaminée JHJ, Weeda EJ, Westhoff V (1995) De Vegetatie van Nederland. Deel 2. Plantengemeenschappen van wateren, moerassen en natte heiden. Opulus Press, Uppsala/Leiden

Schmidt K, Jensen K (2000) Genetic structure and AFLP variation of remnant populations in the rare plant Pedicularis palustris (Scrophulariaceae) and its relation to population size and reproductive components. Am J Bot 87(678-689):23

Schot PP, Wassen MJ (1993) Calcium concentrations in wetland groundwater in relation to water sources and soil conditions in the recharge area. J Hydrol 141:197-217

Schot PP, Barendregt A, Wassen MJ (1988) Hydrology of the wetland Naardermeer: influence of the surrounding area and impact on vegetation. Agric Water Manag 14(1-4):459-470

Sjors H, Gunnarsson U (2002) Calcium and $\mathrm{pH}$ in North and Central Swedish mire waters. J Ecol 90:650-657

Smith AC, Koper N, Francis CM, Fahrig L (2009) Confronting collinearity: comparing methods for disentangling the effects of habitat loss and fragmentation. Landscape Ecol 24:1271-1285

Soomers H, Winkel DN, Du Y, Wassen MJ (2010) The dispersal and deposition of hydrochorous plant seeds in drainage ditches. Freshw Biol 55:2032-2046

Soons MB (2006) Wind dispersal in freshwater wetlands: knowledge for conservation and restoration. Appl Veg Sci 9:271-278

Soons MB, Heil GW (2002) Reduced colonization capacity in fragmented populations of wind- dispersed grassland forbs. J Ecol 90:1033-1043

Suding KN, Collins SL, Gough L, Clark C, Cleland EE, Gross KL, Milchunas DG, Pennings S (2005) Functional- and abundance-based mechanisms explain diversity loss due to $\mathrm{N}$ fertilization. Proc Natl Acad Sci USA 102:4387-4392

Tilman D, May RM, Lehman CL, Nowak MA (1994) Habitat destuction and the extinction debt. Nature 371:65-66

Topografische Dienst (2005) Topografische ondergrond (c), Emmen

Van den Broek T, van Diggelen R, Bobbink R (2005) Variation in seed buoyancy of species in wetland ecosystems with different flooding dynamics. J Veg Sci 16:579-586

Van der Meijden R (1996) Heukels' Flora van Nederland Wolters-Noordhoff bv. Groningen

Van Diggelen R, Molenaar WJ, Kooijman AM (1996) Vegetation succession in a floating mire in relation to management and hydrology. J Veg Sci 7:809-820.

Van der Meijden R, van Duuren L, Weeda EJ, Plate CL (1991) Standaardlijst van de Nederlandse Flora 1990. Gorteria 17:75-127

Vitousek PM, Mooney HA, Lubchenco J, Melillo JM (1997) Human domination of Earth's ecosystems. Science 277:494-499

Wassen MJ, Barendregt A (1992) Topographic position and water chemistry of fens in a dutch river plain. J Veg Sci 3:447-456

Wassen MJ, Barendregt A, Bootsma MC, Schot PP (1989) Groundwater chemistry and vegetation of gradients from rich fen to poor fen in the Naardermeer (The Netherlands). Vegetatio 79:117-132

Wassen MJ, Barendregt A, Schot PP, Beltman B (1990a) Dependency of local mesotrophic fens on a regional groundwater flow system in a poldered river plain in The Netherlands. Landscape Ecol 5:21-38

Wassen MJ, Barendregt A, Palczynski A, De Smidt JT, De Mars H (1990b) The relationship between fen vegetation gradients, groundwater flow and flooding in an undrained valley mire at Biebrza, Poland. J Ecol 78:1106-1122

Wassen MJ, Barendregt A, Palczynski A, De Smidt JT, De Mars H (1992) Hydro-ecological analysis of the Biebrza mire (Poland). Wetlands Ecol Manage 2(3):119-134 
Wassen MJ, Olde Venterink H, Lapshina ED, Tanneberger F (2005) Endangered plants persist under phosphorus limitation. Nature 437:547-550

Wassen MJ, Okruszko T, Kardel I, Chormanski J, Swiatek D, Mioduszewski W, Bleuten W, Querner EP, El Kahloun M, Batelaan O, Meire P (2006) Eco-hydrological functioning of the Biebrza Wetlands; lessons for the conservation and restoration of deteriorated wetlands. In: Bobbink R, Beltman B, Verhoeven JTA, Whigham D (eds) Wetlands functioning, biodiversity conservation and restoration. Springer, Heidelberg, pp 285-310

Whittaker RJ, Nogués-Bravo D, Araújo MB (2007) Geographical gradients of species richness: a test of the water-energy conjecture of Hawkins et al. (2003) using European data for five taxa. Glob Ecol Biogeogr 16:76-89

Zonneveld JIS (1980) Tussen de bergen en de zee, 5th edn. Bohn, Scheltema and Holkema 